ISSN : $1693-9913$

eISSN : $2548-4184$

\title{
THE STRATEGIES USED BY THE GOOD SPEAKER STUDENTS IN DEVELOPING SPEAKING PERFORMANCE AT ENGLISH STUDY PROGRAM DAYANU IKHSANUDDIN UNIVERSITY
}

\author{
La Mido \\ (Lecturer of English Educational Study Program of Dayanu Ikhsanuddin University Baubau)
}

\begin{abstract}
ABSTRAK
Penelitian ini bertujuan untuk menginvestigasi strategi yang digunakan oleh siswa pembicara yang baik pada program studi Bahasa Inggris Universitas Dayanu Iksanuddin dalam meningkatkan keterampilan berbicara mereka. Penelitian ini menggunakan penelitian kualitatif, yang dikategorikan sebagai studi kasus. Subyek penelitian ini adalah 3 mahasiswa Program Studi Bahasa Inggris Universitas Dayanu Ikhsanuddin. Kuesioner adalah instrumen yang digunakan dalam mengumpulkan data.

Temuan penelitian menunjukkan bahwa siswa menggunakan 6 strategi dalam belajar bahasa Inggris, ada, 1) strategi memori: menghafal daftar kata-kata baru, mencoba mengatakan berulang kali atau menulis kata-kata bahasa Inggris baru dalam kalimat, meninjau pelajaran bahasa Inggris sering; 2) strategi kognitif: cobalah untuk berbicara bahasa Inggris dengan teman-teman, meniru ucapan penutur asli, cobalah mengucapkan katakata bahasa Inggris baru, membuat kalimat dalam bahasa Inggris, mendengarkan musik Inggris, menonton film atau video Inggris, membuka kamus atau menerjemahkan google, membaca buku, komik, dan artikel dalam bahasa Inggris, menganalisis pola tata bahasa dari pembicaraan pembicara; 3) strategi kompensasi: mengubah bahasa ibu untuk berbicara, mengulangi kata-kata atau kalimat dengan mitra percakapan mereka untuk mencapai pemahaman yang lebih baik, mencoba menafsirkan atau memprediksi makna yang tepat, menggunakan gerakan dalam bahasa Inggris; 4) strategi metakognitif: menunda produksi pidato untuk lebih memperhatikan para dosen atau teman, mencari peluang dengan berusaha mencari tahu bagaimana bahasa bekerja dengan membaca buku, dan berbicara dengan orang lain, menganalisis pola gramatikal kalimat yang telah ditulis atau diucapkan, mengamati gerakan bibir atau bahasa tubuh; 5) strategi afektif: memotivasi diri sendiri untuk berbicara bahasa Inggris tanpa takut membuat beberapa kesalahan; 6) strategi sosial: meminta pembicara dalam bahasa Inggris untuk mengulang atau berbicara, mengkonfirmasi pemahaman mitra berbicara dalam bahasa Inggris, meminta teman untuk saran dalam bahasa Inggris, berinteraksi dengan teman-teman di media sosial. Berdasarkan hasil, strategi yang terutama digunakan oleh responden adalah strategi kognitif.
\end{abstract}

Kata Kunci : Strategi, Kinerja, siswa

\section{ABSTRACT}

This research aims to investigate the strategies used by the good speaker students at English study program of Dayanu Iksanuddin University in improving their speaking skill. This research applied a qualitative research, categorized as case study. Subject of this research was 3 students of English Study Program Dayanu Ikhsanuddin University. Questionnaire was the instrument used in collecting the data.

Research findings show that the students used 6 strategies in learning English, there were, 1) memory strategies: memorize lists of new words, try to say repeatedly or write new English words in sentence, reviewing English lesson often; 2) cognitive strategies: try to speak English with friends, imitate native speakers' pronunciation, try to say new English words, create sentences in English, listening English music, watch English movies or videos, open dictionary or google translate, reading books, comic, and articles in English, analyzing 
grammar pattern of speakers' talks; 3) compensation strategies: switching mother tongue to speak, repeating words or sentences with their conversation partners to achieve better understanding, trying to interpret or predict exact meanings, using gesture in English; 4) metacognitive strategies: delaying speech production to pay more attention to the lecturers or friends, seeking opportunities by making effort to find out how language works by reading book, and talking with other people, analyzing grammar pattern of the sentences that has written or spoken, observing lips motion or body language; 5) affective strategies: motivating own self to speak English without being afraid make some mistakes; 6) social strategies: ask speakers in English to repeat or speak, confirm speaking partners understanding in English, ask friends for advice in English, interact with friends in social media. Based on the result, the strategy mainly used by the respondents was cognitive strategy.

\section{BACKGROUND}

Speaking is important to be learned and mastered by every individual. Speaking is an activity used by someone to communicate with other. It takes place every where and has become part of our daily activities. When someone speaks, he or she interacts and uses the language to express his or her ideas, feeling and thought. He or she also shares information to other trough communication.

The success in speaking is influenced by strategies used by learners in learning the speaking skill. Chammot \& O'Malley (1990) states that foreign language learners should be equipped with appropriate learning strategies in order to learn target language more effectively and efficiently because language learning is an intentional and strategies effort (1).

One of the most important skills that learners should learn in EFL learning is speaking. Speaking is very important because by mastering speaking learners might express their ideas to another people well so that they might achieve their communication goals. Nunan (1995) states that to most people, mastering the art of speaking is the most important aspect of learning a second or foreign language and success is measured in terms of the ability to carry out a conversation in the language (2).

According to Brown (1994) in Syamsudin (2016) learners might get difficulty in speaking when learners have to focus on forms and function of the language (3). Speaking is no doubt the hardest skill to understand. In Dayanu Ikhsanuddin University, many Students of English study program had difficulties to master speaking skill caused by learners' lack of understanding linguistic elements such as grammar, vocabularies and pronunciation. They had no ideas about what to say, so they tended to keep silent. Besides, many students of English study program did not use English every time to communicate with other people. So, it was common if some students felt that English was one of difficult course. The students had many problems to speak English, but they created some ways or strategies in learning speaking.

According to Wood (2007) "Different student has different way to overcome those problems. Some of the students are successful learners (4). A study by O'Malley and Chamot (1990) reveals that more effective (higher proficiency) students generally use a greater variety of strategies and use them in ways that help the 
student complete language tasks more successfully (5).

There are only some good students can speak well in the class. Moreover, most of them even have joint English competition. To be successful learners, the students have some ways or strategies in learning. The students have their own strategy. Using their own strategy, their learning will be easier and they can understand the material well. To be a good English student, the learners need serious efforts in learning. Learning involves some activities, the students are not enough only come to the class and pay attention to the teacher. However, they must see, observe and understand the condition of the class.
It is important to conduct a research in strategies for developing speaking skill used by students of English Education Department. Moreover, the researcher wanted to contribute for the development of communication at English study program of Dayanu Ikhsanuddin by conducting research in speaking skills' strategies.

The researcher was interested in conducting this research to know what strategies were used by the good speaker students to develop their speaking skills. Based on the explanation above, the researcher conducted a research entitled "The strategies used by good speaker students in developing their speaking performance at English study program Dayanu Ikhsanuddin University".

\section{PROBLEM STATEMENT}

Based on the background above, the researcher formulates the following problems statement: What strategies do the good speaker students have at English Study Program Dayanu Ikhsanuddin University in speaking English?

\section{METHOD OF THE RESEARCH}

This research was categorized as a qualitative research. This qualitative research applied case study approach based on the phenomena that the researcher got at the pre-observation. Gay (2006) stated that case study used to describe and interpret what is there about the condition or relationship, the opinion that have been grown, the process is in progress, consequences or effects that occur, or a growing trend, hence use qualitative research (6). Similarly to Guy, Merriam (1998) also argued that case study is an examination of specific phenomena such as a program, an event, a process, a person, an institution or social group (7).
The subject of this research was the good students in speaking at English Study Program Dayanu Ikhsanuddin University Baubau. For selecting subject of research, the researcher selected the students who once joined a debate competition in province level and debate competition represented by Dayanu Ikhsanuddin University. The number of subject was 6 students. They were chosen because they have good and more experiences to be successful in speaking English than another student. The time of this research was on September until Desember in 2017/2018 academic years.

In order to facilitate the data collection, the researcher used the 
questionnaires as the instrument. The questionnaires were in the forms of Strategy Inventory for Language Learning (SILL) version 7.0 containing 50 items as an instrument for assessing language learning strategies used by the learners. It was developed by Oxford (1990). The questionnaire consisted of three parts: a) remembering more effectively (memory strategies), b) using mental processes (cognitive strategies), c) compensating for missing knowledge (compensation strategies), and the questionnaires used a five-point Likert scale (8).

According to Johnson \& Christensen (2000), method of collection data is technique for physically obtaining data to be analyzed in a research study. Data Collection is standard and systematic procedure to get available data. The procedure to collect the data is the way to get data collection (9). The researcher had to decide and determine right procedure in order to get correct and accurate data. First, the researcher composed a number of questions in questionnaire. After that, the researcher distributed the questionnaire to the students. Then, the researcher collected the questionnaires. Finally, it is ready to analyze the data of the students' strategies in learning speaking.

In analyzing the collected data, the researcher used data analysis developed by Miles and Huberman (1984) that the data analysis consists of three activities, and those are: Data reduction is the process of selecting, focusing, simplifying, and choosing the main data needed. Thus the data reduced will give clearly description and made researcher easy to collect the next data and find out if needed. The steps in analyzing data in this research are, the researcher collected the data through interview. Then the researcher selected, transcribed the interview, made the field note, and focused on the data by referring to the statements of the research problems being investigated in the research. It means the researcher collected the data needed and the irrelevant data should be discarded.

The next activity after data reduction is displaying the data. Data display is a form of analysis that describes what is happening in the natural setting so that it finally can help the researcher to draw a final conclusion. In qualitative research data display can be done in narrative text, chart, and connection between the category, flowchart and other. Miles and Huberman (1984) state "looking at displays help us to understand what is happening and to do some thing-further analysis or caution on that understanding". So, with data display it helped the researcher to understand what was happening and made the next planning. The most frequent form of data display in this research was in the form of narrative text.

Conclusion is the last procedure of analyzing the data in this research. Making conclusion is the process of drawing the content of data collected in the form of good statement and having clear data. After the data is displayed, a conclusion is drawn so that it can be justified scientifically.

\section{FINDINGS AND DISCUSSION}

\section{A. Findings}

Strategies used by good speaker of English students. 
ISSN : $1693-9913$

eISSN : 2548 - 4184

Table 1. Strategy Inventory Language Learning Results by Respondent 1 (CG)

\begin{tabular}{|c|c|c|c|c|c|}
\hline No. & Pernyataan & 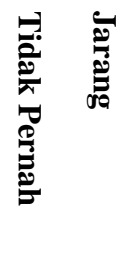 & 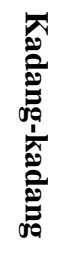 & 窇. & $\frac{\mathscr{Q}}{\mathscr{D}}$ \\
\hline 10. & Saya mengucapkan atau menulis kosakata baru untuk beberapa kali. & & & & $\sqrt{ }$ \\
\hline 11. & $\begin{array}{l}\text { Saya berusaha berbicara seperti seorang penutur asli (native } \\
\text { speaker). }\end{array}$ & & & $\sqrt{ }$ & \\
\hline 12. & Saya berlatih pengucapan bahasa Inggris. & & & & $\sqrt{ }$ \\
\hline 15. & $\begin{array}{l}\text { Saya menonton acara TV atau film di bioskop yang menggunakan } \\
\text { bahasa Inggris. }\end{array}$ & & & $\sqrt{ }$ & \\
\hline 30. & $\begin{array}{l}\text { Saya mencari-cari kesempatan untuk dapat menggunakan bahasa } \\
\text { Inggris. }\end{array}$ & & & $\sqrt{ }$ & \\
\hline 33. & $\begin{array}{l}\text { Saya selalu mencari tahu supaya bisa menjadi pembelajar bahasa } \\
\text { Inggris yang baik. }\end{array}$ & & & $\sqrt{ }$ & \\
\hline
\end{tabular}

Based on the result of questionnaire above, to improve pronunciation, respondent CG always says new English words several times. She often tries to talk like native English speakers. She always practices the sounds of English. She often watches English language TV shows spoken in English or goes to movies spoken in English. She often tries to find as many ways as she can to use her English. She often tries to find out how to be a better learner of English.

Table 2. Strategy Inventory Language Learning Results by Respondent 2 (AA)

\begin{tabular}{|c|c|c|c|c|c|}
\hline No. & Pernyataan & 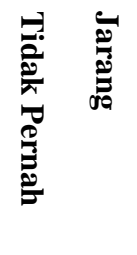 & 忒 & $\stackrel{\mathscr{Q}}{\stackrel{\mathscr{P}}{\Xi}}$ & $\frac{\mathscr{Q}}{\stackrel{\mathscr{C}}{*}}$ \\
\hline 10. & Saya mengucapkan atau menulis kosakata baru untuk beberapa kali. & & & $\sqrt{ }$ & \\
\hline 11. & Saya berusaha berbicara seperti seorang penutur asli (native speaker). & & & & $\sqrt{ }$ \\
\hline 12. & Saya berlatih pengucapan bahasa Inggris. & & & & $\sqrt{ }$ \\
\hline 15. & $\begin{array}{l}\text { Saya menonton acara TV atau film di bioskop yang menggunakan } \\
\text { bahasa Inggris. }\end{array}$ & & & & $\sqrt{ }$ \\
\hline 16. & Saya membaca bacaan-bacaan ringan yang berbahasa Inggris. & & & $\sqrt{ }$ & \\
\hline 30. & $\begin{array}{l}\text { Saya mencari-cari kesempatan untuk dapat menggunakan bahasa } \\
\text { Inggris. }\end{array}$ & & & & $\sqrt{ }$ \\
\hline 33. & $\begin{array}{l}\text { Saya selalu mencari tahu supaya bisa menjadi pembelajar bahasa } \\
\text { Inggris yang baik. }\end{array}$ & & & & $\sqrt{ }$ \\
\hline 36. & $\begin{array}{l}\text { Saya mencari kesempatan sebanyak mungkin untuk membaca bahasa } \\
\text { Inggris. }\end{array}$ & & & $\sqrt{ }$ & \\
\hline
\end{tabular}

Based on the result of questionnaire above, to improve pronunciation, respondent AA often says new English words several times. He always tries to talk like native English speakers. He always practices the sounds of English. He always 
watches English language TV shows spoken in English or goes to movies spoken in English. He often reads some light reading. $\mathrm{He}$ always tries to find as many ways as he can to use his English. He always tries to find out how to be a better learner of English. He often looks for opportunities to read as much as possible in English.

Table 3. Strategy Inventory Language Learning Results by Respondent 3 (RY)

No. Pernyataan

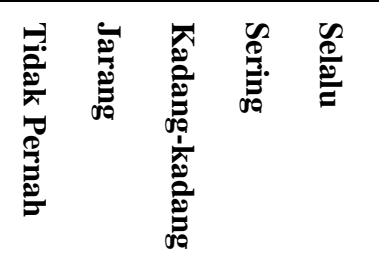

\begin{tabular}{clc}
\hline 10. & Saya mengucapkan atau menulis kosakata baru untuk beberapa kali. & $\sqrt{ }$ \\
\hline 11. & $\begin{array}{l}\text { Saya berusaha berbicara seperti seorang penutur asli (native } \\
\text { speaker). }\end{array}$ & $\sqrt{ }$ \\
\hline 12. & Saya berlatih pengucapan bahasa Inggris. & $\sqrt{ }$ \\
\hline 15. & $\begin{array}{l}\text { Saya menonton acara TV atau film di bioskop yang menggunakan } \\
\text { bahasa Inggris. }\end{array}$ & $\sqrt{ }$ \\
\hline 30. & $\begin{array}{l}\text { Saya mencari-cari kesempatan untuk dapat menggunakan bahasa } \\
\text { Inggris. }\end{array}$ & $\sqrt{ }$ \\
\hline 33. & $\begin{array}{l}\text { Saya selalu mencari tahu supaya bisa menjadi pembelajar bahasa } \\
\text { Inggris yang baik. }\end{array}$ & $\sqrt{ }$ \\
\hline 35. & $\begin{array}{l}\text { Saya memcari teman atau partner yang bisa saya ajak untuk } \\
\text { berbicara bahasa Inggris. }\end{array}$ \\
\hline 47. & Saya berlatih bahasa Inggris dengan teman atau murid yang lain. & $\sqrt{ }$ \\
\hline
\end{tabular}

Based on the result of questionnaire above, to improve pronunciation, respondent RY always says new English words several times. She always tries to talk like native English speakers. She always practices the sounds of English. She always watches English language TV shows spoken in English or go to movies spoken in English. She always tries to find as many ways as she can to use her English. She always tries to find out how to be a better learner of English. She always looks for people she can talk to in English. She often practices English with other students.

Table 4. Strategy Inventory Language Learning Results by Respondent 4 (NZ)

No. Pernyataan

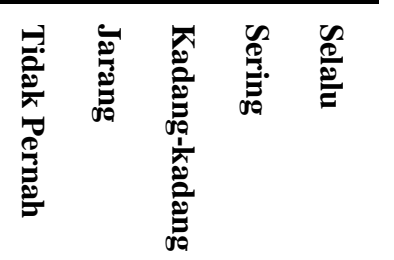

15. Saya menonton acara TV atau film di bioskop yang menggunakan bahasa Inggris.

30. Saya mencari-cari kesempatan untuk dapat menggunakan bahasa Inggris.

33. Saya selalu mencari tahu supaya bisa menjadi pembelajar bahasa Inggris yang baik. 
Based on the result of questionnaire above, to improve pronunciation, respondent NZ always watches English language TV shows spoken in English or goes to movies spoken in English. She always tries to find as many ways as she can to use her English. She always tries to find out how to be a better learner of English.

Table 5. Strategy Inventory Language Learning Results by Respondent 5 (AG)

\begin{tabular}{|c|c|c|c|c|c|}
\hline No. & Pernyataan & 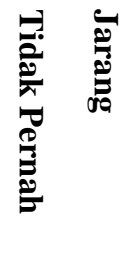 & 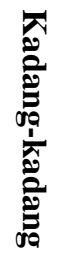 & $\underset{\mathscr{O}}{\mathscr{g}}$ & $\frac{\mathscr{Q}}{\stackrel{\mathscr{Q}}{\ddot{\theta}}}$ \\
\hline 13. & $\begin{array}{l}\text { Saya menggunakan kata-kata bahasa Inggris yang saya tahu } \\
\text { dengan berbagai cara yang berbeda. }\end{array}$ & & & & $\sqrt{ }$ \\
\hline 30. & $\begin{array}{l}\text { Saya mencari-cari kesempatan untuk dapat menggunakan } \\
\text { bahasa Inggris. }\end{array}$ & & & & $\sqrt{ }$ \\
\hline 32. & $\begin{array}{l}\text { Saya memperhatikan ketika seseorang berbicara dalam } \\
\text { bahasa Inggris. }\end{array}$ & & & & $\sqrt{ }$ \\
\hline 33. & $\begin{array}{l}\text { Saya selalu mencari tahu supaya bisa menjadi pembelajar } \\
\text { bahasa Inggris yang baik. }\end{array}$ & & & & $\sqrt{ }$ \\
\hline 35. & $\begin{array}{l}\text { Saya memcari teman atau partner yang bisa saya ajak untuk } \\
\text { berbicara bahasa Inggris. }\end{array}$ & & & & $\sqrt{ }$ \\
\hline 47. & $\begin{array}{l}\text { Saya berlatih bahasa Inggris dengan teman atau murid yang } \\
\text { lain. }\end{array}$ & & & & $\sqrt{ }$ \\
\hline
\end{tabular}

Based on the result of questionnaire above, to improve pronunciation, respondent AG always uses the English words he knows in different ways. He always tries to find as many ways as he can to use his English. He always pays attention when someone is speaking English. He always tries to find out how to be a better learner of English. He always looks for people he can talk to in English. He always practices English with other students.

Table 6. Strategy Inventory Language Learning Results by Respondent 6 (FA)

\begin{tabular}{|c|c|c|c|c|c|c|}
\hline No. & Pernyataan & 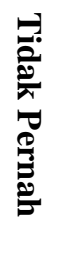 & 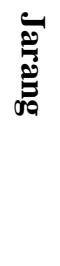 & 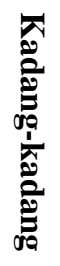 & 㿣 & $\frac{\mathscr{Q}}{\stackrel{\mathscr{Q}}{\ddot{z}}}$ \\
\hline 12. & Saya berlatih pengucapan bahasa Inggris. & & & & & $\sqrt{ }$ \\
\hline 13. & $\begin{array}{l}\text { Saya menggunakan kata-kata bahasa Inggris yang saya tahu } \\
\text { dengan berbagai cara yang berbeda. }\end{array}$ & & & & & $\sqrt{ }$ \\
\hline 14. & Saya biasa memulai percakapan dalam bahasa Inggris. & & & & $\sqrt{ }$ & \\
\hline 30. & $\begin{array}{l}\text { Saya mencari-cari kesempatan untuk dapat menggunakan } \\
\text { bahasa Inggris. }\end{array}$ & & & & & $\sqrt{ }$ \\
\hline
\end{tabular}


No. Pernyataan

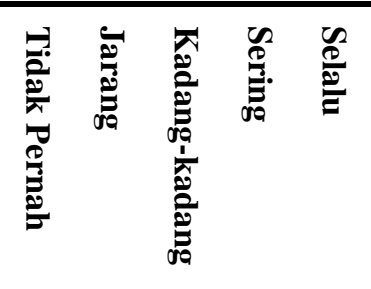

\begin{tabular}{lll}
\hline 31. & $\begin{array}{l}\text { Saya mencari tahu kesalahan bahasa Inggris saya untuk } \\
\text { memperbaiki bahasa saya. }\end{array}$ & $\sqrt{ }$ \\
\hline 33. & $\begin{array}{l}\text { Saya selalu mencari tahu supaya bisa menjadi pembelajar } \\
\text { bahasa Inggris yang baik. }\end{array}$ & $\sqrt{ }$ \\
\hline 35. & $\begin{array}{l}\text { Saya memcari teman atau partner yang bisa saya ajak untuk } \\
\text { berbicara bahasa Inggris. }\end{array}$ & $\sqrt{ }$ \\
\hline 47. & $\begin{array}{l}\text { Saya berlatih bahasa Inggris dengan teman atau murid yang } \\
\text { lain. }\end{array}$ & \\
\hline
\end{tabular}

Based on the result of questionnaire above, to improve pronunciation, respondent FA always practices the sounds of English. She always uses the English words she knows in different ways. She often starts conversations in English. She always tries to find as many ways as she can to use my English. She always notices her English mistakes and uses that information to help her do better. She always tries to find out how to be a better learner of English. She always looks for people she can talk to in English. She always practices English with other students.

Table 7. Strategy Inventory Language Learning Results by Respondent 1 (CG)

\begin{tabular}{ll}
\hline No. & Pernyataan \\
2. & $\begin{array}{l}\text { Saya menggunakan kata-kata bahasa Inggris yang baru saya } \\
\text { ketahui dalam bentuk kalimat supaya saya bisa } \\
\text { mengingatnya. }\end{array}$ \\
\hline 10. $\begin{array}{l}\text { Saya mengucapkan atau menulis kosakata baru untuk } \\
\text { beberapa kali. }\end{array}$ & $\begin{array}{l}\text { Saya menonton acara TV atau film di bioskop yang } \\
\text { menggunakan bahasa Inggris. }\end{array}$ \\
\hline 15. Saya mencari-cari kesempatan untuk dapat menggunakan \\
bahasa Inggris.
\end{tabular}


Based on the result of questionnaire above, to improve vocabulary, respondent CG often uses new English words in a sentence so she can remember them. She always says or writes new English words several times. She often watches English language TV shows spoken in English or goes to movies spoken in English. She often tries to find as many ways as she can to use her English. She often tries to find out how to be a better learner of English. She often looks for people she can talk to in English. She often looks for opportunities to read as much as possible in English. She often practices English with other students.

Table 8. Strategy Inventory Language Learning Results by Respondent 2 (AA)

\begin{tabular}{|c|c|c|c|c|c|}
\hline No. & Pernyataan & 高 & 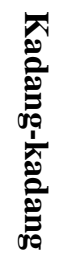 & 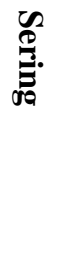 & $\frac{\mathscr{\mathscr { Q }}}{\stackrel{\mathscr{\rho}}{\underline{Z}}}$ \\
\hline 9. & $\begin{array}{l}\text { Saya selalu mengingat kosakata atau frasa baru dengan } \\
\text { mengingat dimana saya melihat kosakata tersebut (halaman } \\
\text { buku, papan tulis, dll). }\end{array}$ & & & $\sqrt{ }$ & \\
\hline 15. & $\begin{array}{l}\text { Saya menonton acara TV atau film di bioskop yang } \\
\text { menggunakan bahasa Inggris. }\end{array}$ & & & & $\sqrt{ }$ \\
\hline 16. & $\begin{array}{l}\text { Saya membaca bacaan-bacaan ringan yang berbahasa } \\
\text { Inggris. }\end{array}$ & & & $\sqrt{ }$ & \\
\hline 22. & $\begin{array}{l}\text { Saya mencoba untuk tidak mengartikan kata-per-kata dalam } \\
\text { sebuah kalimat. }\end{array}$ & & & & $\sqrt{ }$ \\
\hline 27. & $\begin{array}{l}\text { Saya membaca bahasa Inggris tanpa perlu mengecek makna } \\
\text { setiap kosakata baru. }\end{array}$ & & & $\sqrt{ }$ & \\
\hline 30. & $\begin{array}{l}\text { Saya mencari-cari kesempatan untuk dapat menggunakan } \\
\text { bahasa Inggris. }\end{array}$ & & & & $\sqrt{ }$ \\
\hline 33. & $\begin{array}{l}\text { Saya selalu mencari tahu supaya bisa menjadi pembelajar } \\
\text { bahasa Inggris yang baik. }\end{array}$ & & & & $\sqrt{ }$ \\
\hline 36. & $\begin{array}{l}\text { Saya mencari kesempatan sebanyak mungkin untuk } \\
\text { membaca bahasa Inggris. }\end{array}$ & & & $\sqrt{ }$ & \\
\hline
\end{tabular}

Based on the result of questionnaire above, to improve vocabulary, respondent AA often remembers new English words or phrases by remembering their location on the page, on the board, or on a street sign. He always watches English language TV shows spoken in English or goes to movies spoken in English. He often reads some light reading. He always tries not to translate word-for-word. He often reads English without looking up every new word. He always tries to find as many ways as he can to use his English. He always tries to find out how to be a better learner of English. He often looks for opportunities to read as much as possible in English.

\section{B. Discussion}

\section{Strategies Used by Good Speaker of English Students}

The result of questionnaires with the subject, the researcher found some strategies done by the subject. Some of them had different strategies but some of them also had the same strategies in developing their speaking performance. 


\section{a. Memory Strategies}

Memory Strategies related to how students remember language. Based on the result of research from the respondents, researcher found that Memory strategies were used in learning English. The respondents practiced making sentence using new English words in writing form or speaking the sentence with friends, so they can remember them easily. Some of respondents also took a note to list new words of something that they have been looked around when they did not know the words in English. Then, they translated the words. They used the same way for new words in reading storybooks to memorize them easily.

\section{b. Cognitive Strategies}

Cognitive strategies related to how students think about their learning. Cognitive strategies used to help the students to manipulate the target language or task correctly by using all (Hardan, 2013) (10). Based on the result of research from the respondents, researcher found that Cognitive strategies were used in learning English. They trained their accent by repeating and imitating sounds of words, listening to native speakers from songs, and watched English movies so that they can enrich their vocabulary. They practiced speaking frequently with another people or their self. They also frequently practiced speaking lists of words on a note and from lecturer's explanation that has been written. By doing those things over and over, they can become familiar and be able to speak more fluently. They added that they consulted with the dictionaries both in written and audio sources, such as Google Translate, to know how a word is pronounced. They also read comic, story book, grammar book in English and other verbal materials containing grammar patterns.

\section{c. Compensation Strategies}

Compensation strategies enable students to make up for limited knowledge. Based on the result of research from the respondents, researcher found that Compensation strategies were used in learning English. The respondents seeking out or creating opportunities to practice the new language in naturalistic situation, such as going to cinema, or joining English community; CES and EDS. Students tend to predict meaning of their partners, asking for help, when they find it hard to understand what is being said. To make their speech were understood, they explained clearly what they said by using synonym and keeping going the conversation so that they can speak fluently.

\section{d. Meta Cognitive Strategies}

Meta cognitive strategies related to how students manage their own learning. Based on the result of research from the respondents, researcher found that Meta cognitive strategies were used in learning English. The respondents try to do something that helped them to improve their speaking skill after knowing their skills bound. They did some activities such as consultation with their friends especially who has good ability in English and study from the dictionary in order to improve their speaking skill. They observed their partner's lips body languages. They also delayed their speech by paying more attention to the speakers such as their partners or lecturers.

Purpura (1999) found that Meta cognitive strategies had "a significant, positive, direct effect on cognitive strategy use, providing clear evidence that Meta cognitive strategy use has an executive function over cognitive strategy use in task completion"(11). 


\section{e. Affective Strategies}

Affective strategies related to students' feelings. Based on the result of research from the respondents, researcher found that Affective strategies were used in learning English but the strategies were rarely used. To encourage their selves, some of respondents, even though they felt some of his sentences that said were not correct enough when discussing with friends in English, they did not think about the mistake in speaking. They let it happen in order to he did not speak English haltingly.

\section{f. Social Strategies}

Social strategies involved learning by interaction with others. Based on the result of research from the respondents, researcher found that Social strategies are used in learning English. Students tend to ask their partners spoke slowly and asked for confirmation of their speaking partners understanding. The students' activities, especially their English conversation practiced in daily activities to improve their speaking ability. According to the results, the students really want to practice their speaking with the others, but there was little chance only to speak English each other especially in the class. Then, they prefer to practice their speaking by social media and join English community such as CES or EDS.

Social strategies were significantly associated with L2 proficiency in studies by the South African EFL study by Dreyer and Oxford (1996) and the investigation of native-English-speaking foreign language learners by Oxford and Ehrman (1990) (12).

\section{CONCLUSION AND SUGGESTION}

\section{A. Conclusion}

Of the six learning strategies provided by Oxford, the English student of Unidayan used six learning strategies in speaking. They are memory strategies, cognitive strategies, compensation strategies, meta cognitive strategies, affective strategies, and social strategies. In using the strategies, not every strategies used by them. For memory strategies there were Memorizing lists of new words, Try to say repeatedly or write new English words in sentences and Reviewing English lesson often. For cognitive strategies, the students used speaking English with friends, Imitating native speakers' pronunciation, creating sentences in English and Watching English movies or videos. For compensation strategies, the learners applied Switching mother tongue to speak, Repeating words or sentences with their conversation partners to achieve better understanding, and interpreting or predicting exact meanings.
For meta cognitive strategies, they were Delaying speech production to pay more attention to the lecturers or friends, Seeking opportunities by Making effort to find out how language works by reading book, and talking with other people and Analyzing grammar pattern of the sentences that has written or spoken. For affective strategies the students only motivating own self to speak English without being afraid make some mistakes. The last strategies used by English learners were asking speakers in English to repeat or speak, Confirming speaking partners and understanding in English and Interacting with friends in social media.

\section{B. Suggestion}

The students should applying varieties learning strategies to become success learners. It is suggested that using appropriate strategies in learning speaking based on the right situation and condition in getting good speaking performance. 


\section{REFFERENCES}

1. O'Malley, J and Chamot, A.U. 1990. Learning Strategies in Second Language Acquisition. Cambridge: Cambridge University Press.

2. Nunan, D. 1995. Language Teaching Methodology. New York: Prentice Hall.

3. Syamsudin. 2016. The Use of Non Linguistics Means Strategies as a Speaking-problem Solving in EFL Learning. International Journal of English Language Education: Vol. 4, No. 2: 2016. Makrothink Institute.

4. Wood, D. 2007. Kiat Mengatasi Gangguan Belajar. Katahati: Jogjakarta.

5. Gay, et al. 2006. Educational Research. New Jersey. Pearson Prentice Hall.

6. Merriam, S.B. 1998. Qualitative Research and Case Study Application in Education. San Francisco: Jossey-Bass Publishers.

7. Oxford, R.L. 1990. Language Learning Strategies: What Every Teacher Should Know?. Boston: Heinle \& Heinle.

8. Johnson, B., \& Christensen, L. 2000. Educational Research, Quantitative and Qualitative Approaches. USA: Allyn and Bacon. https://afidburhanuddin. wordpress.com/2013/09/24/teknikpengumpulan-data-3/. (Accessed on June 7, 2017).

9. Hardan, A.M. 2013. Language Learning Strategies: A General Overview. Social and Behavior Sciences: 106, 1712-1726. Procedia.

10. Purpura, J. 1999. Learner characteristics and L2 test performance. In R. L. Oxford (Ed.), Language Learning Strategies in the Context of Autonomy, Synthesis of Findings from the International Invitational Conference on Learning Strategy Research (pp. 61-63). Teachers College, Columbia University, New York.

11. Dreyer, C. \& Oxford, R. 1996: Learning strategies and other predictors of ESL proficiency among Afrikaansspeakers in South Africa. In R. Oxford (Ed.), Language Learning Strategies Around the World: Cross-cultural Perspectives (pp. 61-74). Manoa: University of Hawaii Press.

12. Ehrman, M. \& Oxford, R. 1990. Adult Language Learning Styles and Strategies in an Intensive Training Setting. Modern Language Journal: 74, 311-326. 